\title{
Foreign Direct Investment in Nepal
}

\author{
Biraj Pyakurel, PhD \\ Reader, Nepal Commerce Campus, \\ Minbhawan, Kathmandu, Tribhuvan University \\ Email for correspondence: ritiriwaj@gmail.com
}

\begin{abstract}
Foreign Direct Investment (FDI) is an important source of capital for economic growth in developing countries. It provides a package which constitutes new technologies, management techniques, finance and market access for the production and movement of goods and services. However, attracting FDI is a major challenge for host countries as it faces the challenge of identifying the major factors that motivate and affect the FDI location decision. The main FDI location factors are cost, market infrastructure, and technological, political, legal and socio-cultural factors. Despite several conflicting circumstances, Nepal is attempting to sort out overarching issues of FDI concerning with economic development. That's why Nepal is at a point where from it can excel for economic goals via FDI. The set trends illustrate that various indicators pertaining to FDI in the country has been improving since peace process was begun in 2006. This analysis comes to conclusions that the country owns unique advantages and, thereby, opportunities of FDI useful for the country's prosperity. Yet FDI in the country is not free of challenges, thus, that need to be timely addressed with prudent measures.
\end{abstract}

Key words: Foreign direct investment, developing countries, economic goals and economic growth.

\section{Setting the Scene}

The home of mountains, sheltering the world biggest mountain "Mount Everest", with Birth place of Light of Asia "Siddhartha Gautama Buddha" is a typical introduction to Nepal. Despite of acquiring world eight out of tenth biggest mountains; filled with plenty of medicinal herbs; it has failed to attract enormous foreign investors. A country equipped with enormous natural beauties, and all-time favorable climate is desperately lacking a term, Foreign Direct Investment. The investment made in any country by foreign investors, that is, entrepreneurs and institution is known as foreign direct investment (FDI). FDI is rapidly growing in developing countries. The theoretical study highlights the perfect market theory and imperfect market theories of FDI. FDI is an important source for the developing countries, which has plenty of resources but is economically weak with a deficiency in finance, technology and competitive management. FDI introduces new technology, knowledge, skills, new management practices, etc. to the recipient economy. Based on Investment across Borders Reports (2010), World Bank points the benefits of FDI as a global network of 80,000 multinational corporations and 800,000 foreign affiliates have helped create millions of jobs, transferred technology, modern skills, fostered 
competition, and contributed to the fiscal standing of many economies. Normally investment is regarded as imperative factors of aggregate demand, which eventually affects the level of aggregate supply in the economy. An investment is usually done to accelerate the available resources aiming a future returns.

The benefits of foreign direct investment to both host and investor economies are generally recongnised, and there is a wide demand for reducing or eliminating barriers to global FDI integration. In the past few decades, continuous effort in multilateral trade negotiations, regional trade agreements, bilateral and multilateral investment accords have, to some extent, reduced obstacles to FDI. The World Trade Organization (WTO) has made trade negotiations aims at continuing this trend. Thus, it is not surprising to see that FDI flows have increased dramatically in recent decades.

Foreign direct investment plays vital role in developing countries for foster national economic growth. FDI creates employment opportunities, raise the level of domestic wages, faster economic growth and improve the distribution of income. FDI has not been widely practiced in Nepal. With the settlement of political conflicts, a growing number of international projects are willing to assure in Nepalese economy. FDI tends to increase in the near future in Nepal. Nepal needs FDI to have very good infrastructural development like road network, waterways, and airways. The domestic capital is inadequate since this sector needs very huge investments. FDI is needed for Nepal to boost the industrialization process from running stage to take off stage. Government of Nepal is incapable to attract the foreign investors to invest in Nepal. There are various factors create a substantial problem in the inflow of FDI in Nepal that directly affect the economy preventing a growth of production, employment and income. Even though, the country is bountiful of numerous positive attributes. Trade policy and trade strategy has succinctly identified sectors having comparative advantages. Prudent monetary, fiscal and trade policies have created a modern and stable macroeconomic framework with the potential to create a dynamic, competitive, and investment attracting economy in the decade ahead. Above all, conclusion of political settlement, labor unrest and power crisis are the critical factors. However, political agenda and economic agenda have to move in a best synchronized way. Provided the conditions, a potential influx of FDI is at the country's door step but due to knock its door

In recent years, Government of Nepal has accorded a top priority to attract foreign direct investment. Especial emphasis had been given since Ninth Plan to mobilize foreign investment. For this purposes the government have adopted various policies. The FDI in Nepal is not at the peak, as it needs to be. The flow of inward FDI was at peak during mid-1990s and thereafter declined due to country's civil war of Maoist insurgency. However, as Maoist ended up the decade's civil war and joined the Government, presently Nepal is creating a peaceful environment for the Foreign Investors. The political disputes are cooling, and several foreign investors are keeping an eye to Nepal. Nepal's FDI projects include mostly in manufacturing, hydropower, mineral exploitation, construction, agro based, chemicals, tourists hotels and restaurants, specialized services and in food and beverage industries. By the year 2005, Hotel \& Resorts undertook 440 projects under manufacturing industries followed by 227 projects. In context to approved FDI projects, more than 40 percent of investment comes from India; and the rest comes from USA, Norway, Japan, Singapore, Bermuda, China, U.K., South Korea, Italy, Netherlands, Thailand, Philippines, Germany, Switzer-land, France, Taiwan, Bangladesh, Pakistan, Australia, British Virgin Island, Canada, Malaysia, Finland, etc. Nepal has been widely entertaining most of its FDI in Manufacturing industries. The low labor cost might have pursued it. More than 32 
percent of its total investment has been only in Manufacturing projects. Some of globally renowned companies operating are British American Tobacco (BAT), Unilever and Coca-Cola.

\section{Methods}

The objectives of the study was to assess volume and status of FDI (i.e. sectr wise, country wise and district wise) and to analyze contributions of FDI on employment genereations. In this respect, based on secondary data, the study followed descriptive/explainatory research approach. Financial reports and policies published by government of Nepal and other authors have been reviewed. The online articles and news concerning FDI, trends of FDI, are also reviewed. More specifically, FDI data up to 2011 has been used. In this study simple bar diagram and tables are used to analyse the collected data.

\section{Finding I: Volume of FDI}

The volume of FDI inflows to Nepal has historically been very low. During 1980-1989, FDI flows to Nepal were minimal or even negative, with an annual average of Rs.45 million. There was a distinct acceleration during the 1990s, although total flows remained small: averaging Rs.18 billion per annum during 1990-2000. One factor explaining the increased FDI in the 1990s is Nepal's more liberal trade policy. For example, the unweighted average rate of import tariff was drastically reduced from 111 percent in 1989 to 16 percent by 1992; and the number of tariff slabs fell from more than 100 in the 1980s to only 5 in 1996 (Research and Information System [RIS], 2002). In addition, the establishment of bonded warehouses and the introduction of a duty drawback scheme reduced the previous trade policy's anti-export bias. Complementing this overall trade reform programme was a bilateral trade treaty with India concluded in 1996, which allowed India to import goods from Nepal free of import duty and quantitative restrictions if the goods were manufactured in Nepal (except those on the negative list). This has been cited as an explanation of the considerable expansion of Indian investment in Nepal after 1996 (RIS, 2002). Another factor was the liberalization of the exchange rate regime. The currency was made partially convertible in the current account in March 1992 and fully convertible in February 1993. Since 1994 all individuals and firms have been allowed to open accounts in major convertible currencies with domestic banks after showing evidence of the source of foreign exchange. However, in spite of these policy measures, Nepal's receipt of FDI remained low (United Nations Conference on Trade and Development [UNCTAD], 2003). Foreign investment projects can be seen in table 1.

Table 1. Foreign Investment Projects in Nepal

(From beginning to FY 2010/11, NRs in million)

\begin{tabular}{llllll}
\hline Fiscal Year & Number & $\begin{array}{l}\text { Total Project } \\
\text { Cost }\end{array}$ & $\begin{array}{l}\text { Total Fixed } \\
\text { Cost }\end{array}$ & $\begin{array}{l}\text { Foreign } \\
\text { Investment }\end{array}$ & Employment \\
\hline Up to 1988/89 & 58 & 5102.8 & 4271.6 & 449.56 & 10586 \\
$1989 / 90$ & 30 & 2438.19 & 2139.6 & 398.51 & 9515 \\
$1990 / 91$ & 23 & 863.56 & 690.74 & 406.28 & 2974 \\
$1991 / 92$ & 38 & 3508.17 & 2902.1 & 597.84 & 5615 \\
$1992 / 93$ & 64 & 17886.22 & 16210.81 & 3083.67 & 13873 \\
$1993 / 94$ & 38 & 3733.23 & 3175.66 & 1378.76 & 4734 \\
$1994 / 95$ & 19 & 1627.28 & 1247.85 & 477.59 & 2386
\end{tabular}

(Continued...) 
(Table 1 . continued...)

\begin{tabular}{llllll}
$1995 / 96$ & 47 & 10047.47 & 9398.54 & 2219.86 & 8032 \\
$1996 / 97$ & 77 & 8559.25 & 6692.15 & 2395.54 & 9347 \\
$1997 / 98$ & 77 & 5569.38 & 5142.32 & 2000.28 & 4336 \\
$1998 / 99$ & 50 & 5324.42 & 4380.17 & 1666.42 & 2146 \\
$1999 / 00$ & 71 & 2669.09 & 1910.24 & 1417.61 & 4703 \\
$2000 / 01$ & 96 & 7917.62 & 6122.49 & 3102.56 & 6880 \\
$2001 / 02$ & 77 & 3318.53 & 1559.59 & 1209.65 & 3731 \\
$2002 / 03$ & 74 & 4921.82 & 3608.25 & 1793.77 & 3572 \\
$2003 / 04$ & 78 & 4323.74 & 3775.86 & 2764.8 & 2144 \\
$2004 / 05$ & 63 & 1796.1 & 1149.49 & 1635.77 & 5559 \\
$2005 / 06$ & 116 & 4121.08 & 3296.95 & 2606.31 & 7358 \\
$2006 / 07$ & 188 & 3425.57 & 2650.56 & 3226.79 & 7389 \\
$2007 / 08$ & 213 & 20406.38 & 16897.97 & 9812.6 & 10709 \\
$2008 / 09$ & 231 & 9417.89 & 7530.02 & 6255.09 & 11108 \\
$2009 / 10$ & 171 & 13953.78 & 14987.98 & 9100 & 7848 \\
$2010 / 11$ & 209 & 11250.19 & 9375.46 & 10050.71 & 10887 \\
Total & $\mathbf{2 1 0 8}$ & $\mathbf{1 5 2 1 8 1 . 7 5}$ & $\mathbf{1 2 9 1 1 6 . 3 9}$ & $\mathbf{6 8 0 4 9 . 9 7}$ & $\mathbf{1 5 5 4 3 2}$ \\
\hline
\end{tabular}

(Department of Industry, 2011).

The above table reflects that total 2108 projects have been registered in Nepal comprising seven categories of industries, worth a total of investment equal to Rs.152 billion. The total fixed cost is estimated to be Rs. 129 billion while the total foreign direct investment (FDI) is estimated to be Rs.68 billion as of July 2011. The registered projects provided employment to 155,432 people.

\section{Finding II: Sector Wise Distribution of FDI}

The distribution of FDI in Nepal shows that there is investment in various sectors. But some sector has got more priority while the other one has given less priority. The distribution of foreign investment is shown in table 2 .

Table 2. Sectorial Distribution of Foreign Investment Projects

(From beginning to FY 2010/11, NRs in million)

\begin{tabular}{lllllllll}
\hline $\begin{array}{l}\text { Types of } \\
\text { Industries }\end{array}$ & No. & $\begin{array}{l}\text { Total } \\
\text { Project } \\
\text { Cost }\end{array}$ & $\begin{array}{l}\text { Total } \\
\text { Fixed Cost }\end{array}$ & $\begin{array}{l}\text { Foreign } \\
\text { Investment }\end{array}$ & Employment & $\begin{array}{l}\text { Share } \\
\text { in FDI }\end{array}$ & $\begin{array}{l}\text { Share in } \\
\text { projects }\end{array}$ & $\begin{array}{l}\text { Share in } \\
\text { Employment. }\end{array}$ \\
\hline Agriculture & 60 & 1674.42 & 1095.61 & 893.29 & 3497 & 1.31 & 2.85 & 2.25 \\
Construction & 42 & 3605.34 & 2683.10 & 2762.81 & 3016 & 4.06 & 1.99 & 1.94 \\
Energy Based & 47 & 40759.24 & 40381.02 & 14518.77 & 7947 & 21.34 & 2.23 & 5.11 \\
Manufacturing & 712 & 54611.18 & 40355.50 & 25595.87 & 78409 & 37.61 & 33.78 & 50.45 \\
Mineral & 36 & 5162.62 & 4223.60 & 2904.24 & 5574 & 4.27 & 1.71 & 3.59 \\
Service & 650 & 25955.40 & 21220.18 & 12974.65 & 32127 & 19.07 & 30.83 & 20.67 \\
Tourism & 561 & 20413.55 & 19157.38 & 8400.34 & 24862 & 12.34 & 26.61 & 16.00 \\
Total & $\mathbf{2 1 0 8}$ & $\mathbf{1 5 2 1 8 1 . 7 5}$ & $\mathbf{1 2 9 1 1 6 . 3 9}$ & $\mathbf{6 8 0 4 9 . 9 7}$ & $\mathbf{1 5 5 4 3 2}$ & $\mathbf{1 0 0 . 0 0}$ & $\mathbf{1 0 0 . 0 0}$ & $\mathbf{1 0 0 . 0 0}$ \\
\hline
\end{tabular}

(Department of Industry, 2011). 
The above table reflects that FDI is highly concentrated in the manufacturing sector, which accounted for 33.78 percent of approved FDI projects, 37.61 percent of foreign investment. It is followed by service sector with over 30.83 percent of approved projects, 19.07 percent of foreign investment. Tourism stands in third position with 26.61 percent of approved projects, 12.34 percent of foreign investment. The energy based sector, though comes at fourth position by share in approved projects, it is second highest to attract the FDI with 21.34 percent of total foreign investment. The mineral sector stands at last with 1.71 percent of approved projects, 4.27 percent of foreign investment. In sector wise FDI it is found that on agriculture there is only NRs. 893.29 million investments, which is the lowest investment area. On construction sector also the foreign investment is only NRs. 2762.81 million. In mineral and tourism sector also the investment is very low. In service and energy based sector the foreign investment is 12974.65 and 14518.77 million respectively. Looking at the potentiality of these sectors the foreign investment is very low. The investment on manufacturing seems to be the highest, which is NRs. 25595.87 million.

\section{Finding III: Country Wise Distribution of FDI}

In country-wise distribution, five countries accounts for about $65 \%$ of cumulative FDI, shown in table 3 .

Table 3. Country Wise Distribution of FDI

(From beginning to FY 2010/11, NRs in million)

\begin{tabular}{llllllll}
\hline S.N. & Top Countries & $\begin{array}{l}\text { No. of } \\
\text { Projects }\end{array}$ & $\begin{array}{l}\text { Total Project } \\
\text { Cost }\end{array}$ & Total Fixed Cost & FDI & Employment & $\begin{array}{l}\text { Share in } \\
\text { FDI }\end{array}$ \\
\hline 1 & India & 501 & 62725.01 & 51118.64 & 32390.31 & 56407 & 47.60 \\
2 & China & 401 & 13547.54 & 10899.31 & 7036.17 & 23325 & 10.34 \\
3 & Canada & 25 & 5081.87 & 4892.78 & 2166.54 & 1926 & 3.18 \\
4 & Japan & 154 & 3195.03 & 2713.48 & 1171.24 & 6683 & 1.72 \\
5 & Norway & 12 & 8116.59 & 6766.8 & 1135.83 & 726 & 1.67 \\
& Gross Total & $\mathbf{2 1 0 8}$ & $\mathbf{1 5 2 1 8 1 . 7 5}$ & $\mathbf{1 2 9 1 1 6 . 4}$ & $\mathbf{6 8 0 4 9 . 9 7}$ & $\mathbf{1 5 5 4 3 2}$ & $\mathbf{1 0 0 . 0 0}$ \\
\hline
\end{tabular}

(Department of Industry, July 2011).

The above table reflects that India alone accounts for 47.6 percent, followed by China with 10.34 percent, Canada with 3.18 percent, Japan with 1.72 percent and Norway with 1.67 percent. In total, investors from 70 different countries have invested in Nepal, but the scale and number of projects in most cases is small.

\section{Finding IV: District Wise Distributions of FDI}

According to the data up to FY 2010/2011 derived from the government source geographical distribution of FDI within Nepal is strongly concentrated in the Kathmandu Valley, which includes the capital city, Kathmandu, and offers the best infrastructure (transportation, power and telecommunications) and proximity to administrative decision centers. More so, 34 percent of total FDI-related projects are located in this region. Little FDI is found in Nepal's hilly and mountainous region, although it is inhabited by more than half of Nepal's population. The FDI projects are located in the Terai region 
is also in a very low percentage. It shows that FDI in Nepal in various sectors is concentrated in the capital. The table 4 shows the district hosting foreign Direct Investment.

Table 4. Districts Hosting FDI up to 2010/2011

\begin{tabular}{llll}
\hline No & District & Amount in (million) & Percentage \\
\hline 1 & Kathmandu & 23477.00 & $34.49 \%$ \\
2 & Lalitpur & 7101.97 & $10.44 \%$ \\
3 & Kaski & 4130.58 & $6.06 \%$ \\
4 & Rupandehi & 2958.59 & $4.34 \%$ \\
5 & Parsa & 2052.85 & $3.41 \%$ \\
6 & Makawanpur & 2321.73 & $3.41 \%$ \\
7 & Dhading & 2171.00 & $3.19 \%$ \\
8 & Bara & 2072.08 & $3.04 \%$ \\
9 & Others & $21,764.17$ & $31.62 \%$ \\
Total & & $\mathbf{6 8 , 0 4 9 . 9 7}$ & $\mathbf{1 0 0 \%}$ \\
\hline
\end{tabular}

(Department of Industry, 2011).

The above table reflects that FDI in Nepal varies district wise. The table of up to fiscal year 2-10/2011 depicts a very uneven picture of FDI hosted by various administrative districts. In a case of hosting FDI above NRs 2000 million, Kathmandu is the front-runner which is followed by seven other countries. The others include Lalitpur, Kaski, Rupandehi, Parsa, Makawanpur, Dhading and Bara. In quantum, a huge variance was observed between the districts located in the Kathmandu Valley and the other districts. Out of the total FDI alone Kathmandu based two districts scores 44.93 percent, while the later group possesses only 55.07 percent. Likewise, the stated eight districts invited 68.38 percent whereas the rest 11 other districts could attract the remaining 31.62 percent of the total FDI. By and large, the FDI is glued with a certain urban centers that cater a huge number of customers.

\section{Finding V: Sector Wise Employment Generated by FDI}

Foreign direct investment is providing the opportunities of employment for the Nepalese people. The people are engaged in various sectors. This has been possible only due to FDI. To increase the employment rate FDI has to be increased. For this government has to make various policies to attract the foreign investment. From the beginning to fiscal year 2010-11 the sector wise employment is shown in figure1.

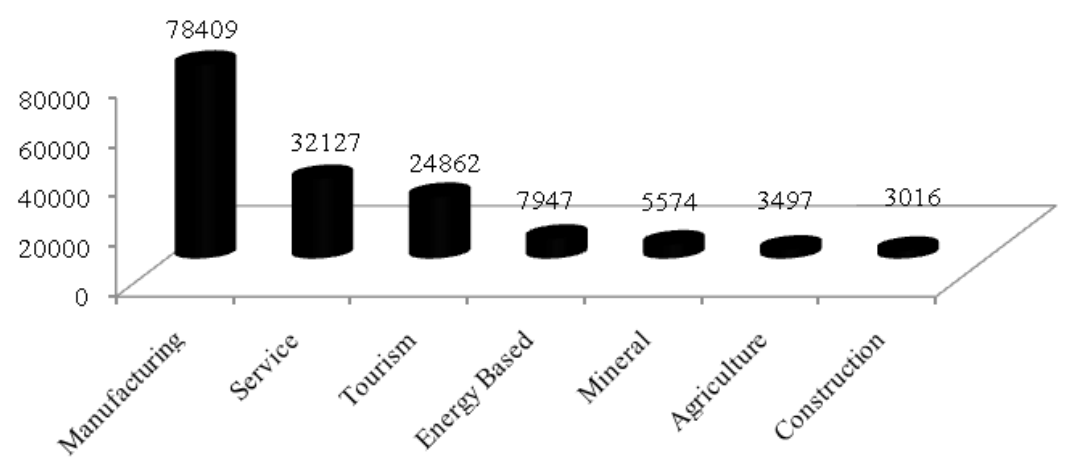

Figure 1. Sector Wise Employment Generated by FDI

NUTA JOURNAL, 5 (1\&2), 2074 : ISSN: 2616 - 017x 
(Department of Industry, 2011).

The above figure reflects that the number of employment from FDI in different sectors is not in same rate. Total employment is 155432 which are engaged in various sectors. The employment from high rate to low rate is shown in the above chart. According to the bar diagram employment from foreign direct investment is highly concentrated in the manufacturing sector, where 78409 people are employed in this sector, which accounted over 50 percent of total employment. It is followed by service sector where 32127 numbers is employed, with 20.67 percent of total employment. Tourism stands in third position with 24862, which becomes 16 percent of total employment. In energy based sector total employment is 7947 which contributes 5.11 percent of total employment. Agriculture sector is the second last sector where only 3497 employment is contributed which is 2.25 percent of total employment and construction sector is the last sector which gives employment to only 3016 which is only 1.94 percent of the total employment.

\section{Conclusion}

The political instability, resultant policy and legal uncertainty do not seem to offer a hospitable investment climate to the foreign investors in Nepal. Militancy of trade unions, which have become emboldened particularly in the aftermath of the declaration of Nepal as a republic, has created havoc for the overall business climate of the country. Despite various inter-locked issues, controversies and transitional political circumstances, Nepal is well positioned among low-income economies to move emphatically on development policy and spending priorities during the next decade. However, there isn't much investment, neither by the foreign countries, nor by neighboring country. And rate of FDI is not increasing at a required rate. Towards end this, political, business, bureaucratic leaders are required to come closer and act in a business-friendly chorus. The whole gambit of course ends with aggressive marketing that Nepal is ripe for hosting FDI. The employment rate in various sectors has to be increased to generate employment situation in Nepal.

\section{References}

Agrawal, J. P. (2000). Economic impact of foreign direct investment in south Asia. Indira Gandhi Institute of Development Research, Gen. A. K. Bombay: India.

Agarwal, J. P. (1980). Determinants of Foreign Direct Investment. Weltwirst schaftliches Achieve, 116.

Balasubramanyam, V. N., Salisu, M. \& Spas, D. F. (1996). Foreign direct investment and economic growth in EP an IS countries. Economics Journal, 106, 92-105.

Magnus, B., Ari, K. \& Zejan, M. (2000). Determinants of Foreign Direct Investment: firm and Hostcountry strategies. Basingstoke, Hampshire RG21 6XS and New York, N.Y. 10010 Palgrave Publisher Ltd (p.1-20,101-105,177-179,221- 225).

Bijit, B. (2002). Determinants of Foreign Direct Investment: Research Issues, 11, 28-30. London: New Fetter Lane, EC4P 4EE. Rutledge.

Buckley, P. J. (1988). The limits of explanation: Testing the internalization theory of the multinational enterprise. Journal of International Business Studies, 19.

Buckley, P. J. \& Casson, M. C. (1996). The future of multinational enterprise. London: Palgrave Macmillan.

Caves, R. E. (1982). Multinational enterprise and economic analysis. Cambridge University Press. 
Choe, J. I. (2003). Do foreign direct investment and gross domestic investment promote economic growth? Revision of Development Economics, 7, 44-57.

Dale, R., Weigel, N. F., Gregory, D. \& Wagle, M. (1997). Foreign Direct Investment. Washington DC: IFC and Foreign Investment Advisory Service.

Joshi, S. K. (2066). Macroeconomics. Kathmandu: Taleju Prakashan, Bhotahity.

Ministry of Industry (MOI) (2009). Nepal: Foreign Investment Opportunities. Government of Nepal.

Ministry of Commerce and Supply (MOCS). (2009). Nepal: Foreign Investment Opportunities. Government of Nepal.

Research and Information System (RIS). (2002). South Asian Development and Cooperation Report 2001/02. New Delhi: India.

United Nations Conference on Trade and Development (UNCTAD). (2003). World Investment Report: FDI Policies for Development: National and International Perspectives. New York: Author. 